\title{
EXTENSION OF AGRICULTURAL RESEARCH IN QUEENSLAND, AUSTRALIA
}

\begin{abstract}
A
NEW research centre for the Commonwealth Scientific and Industrial Research Organization is to be established at Townsville, in northern Queensland. The centre will fill an important gap in northern Australian research. It will consist of research laboratories and an associated field station of 5,000 acres. The Government will provide a capital sum of $£ 300,000$ to finance the venture, and the annual expenditure on research will rise within a short time to $£ 110,000$.

The programme of research at Townsville will combine pasture, soil and animal studies. Scientists based at the new centre will work in an area of about one-third of Queensland, extending from Rockhampton to Cape York.

The Organization already has pasture research stations in the Kimberleys, at Katherine, Darwin, Alice Springs, Brisbane, and in the southern States. When the Townsville project is completed, the Organization will be working in every large area of Australia which has a high pastoral potential.

The new laboratories will be built on land adjacent to the University of Queensland's Townsville site. The Government has provided $£ 50,000$ this financial year for the purchase of land. The laboratories will have a staff of about fifty, including ten research officers.

The new laboratories and station will become part of the Organization's Division of Tropical Pastures which, under the direction of Dr. J. Griffiths Davies, has carried out pasture research in south-eastern Queensland for several years. The results achieved by this Brisbane-based group have been so promising that the Government now feels it is time to extend the work to northern Queensland.

The research programme will be carried out in the Townsville hinterland, the Cairns hinterland, the northern brigalow lands, the northern speargrass
\end{abstract}

region, and the coastal regions. South of Townsville, the area will extend into central eastern Queensland as far as the northern limits of the area being studied from Brisbane.

The research work will be carried out in collaboration with the Queensland Department of Agriculture and Stock and local graziers. It will include a vigorous programme of testing new introduced pasture species and mixtures. Soil scientists will undertake research into soil deficiencies, and animal and pasture management practices will be studied.

By overcoming stock nutritional deficiencies through the development of improved pasture and fodder crops, this new research programme should help to raise stocking-rates, improve calving percentages, reduce losses to breeders, produce marketable animals at younger ages, increase the percentage turn-over, etc.

At present, more than two million beef cattle, or about one-third of Queensland's beef cattle population, are reared in these regions. It is confidently expected that, in many places, present production can be increased several-fold.

The Organization's Division of Land Research and Regional Survey has already conducted extensive regional surveys in the Townsville and Gulf of Carpentaria areas and is at present making a survey of the Fitzroy Basin in central eastern Queensland. These surveys will provide a basis for future pasture development work.

The research programme will be complemented by the work of the Organization's National Cattle Breeding Station at Belmont, near Rockhampton, and the Division of Entomology's cattle tick research station at Ingham. At Belmont, scientists are studying the selection of cattle for better adaptation to tropical conditions, faster growth-rate, and greater efficiency of food utilization.

\section{THE PRIMATES}

\begin{abstract}
A SYMPOSIUM on the primates was held during April 12-14 at the Zoological Society of London, sponsored by the Society in collaboration with the Anatomical Society and the Society for Human Biology. Dr. J. R. Napier, the organizing secretary, had arranged a diverse programme and had invited numerous overseas specialists, some of whom, unfortunately, were unable to be present. This necessitated some changes in the published programme.

The first day, under the chairmanship of Sir Solly Zuckerman, was devoted to aspects of primate behaviour in the wild and in captivity, and included papers by Prof. K. R. Hall (ecology of the chacma baboon, Papio ursinus), Jane Morris-Goodall (ecology and behaviour of free-ranging chimpanzees), Rosalie Osborn (behaviour of mountain gorilla), A. Kortland (protohominid behaviour), R. Andrew (evolution of vocalization), J. A. H. van Hooff (facial expression), and the Rev. J. Cole (research on Macaca nemestrina).
\end{abstract}

A short film on the so-called ufiti of Nyasaland was shown by Dr. W. C. Osman Hill.

Prof. Hall's contribution added considerably to our knowledge of the social structure, group-composition, feeding behaviour and daily activities of the chacma in several areas of South and South-west Africa, and Southern Rhodesia. Of interest was his observation that in the Drakensbergs baboons range up to the snow-line. Rosalie Osborn exhibited the gorilla film prepared by Dr. Schaller and kindly loaned by the New York Zoological Society. In addition to her commentary, she added remarks on her own first-hand acquaintance with the gorillas in Western Uganda. Emphasis was laid on their essential quadrupedality and lack of brachiation; data were given on feeding activities and nesting procedure.

The well-documented contribution from Miss $\mathrm{J}$. Morris-Goodall was received with much enthusiasm. Her sixteen months close contact with wild chimpan- 
zees in Tanganyika was fully recorded in film and photograph, and the results included convincing evidenco of tool-using by the ape, especially application of sticks and straws to probe ants nests for the purpose of collecting the ants for food. There was a noted preferential use of the left hand in this procedure. Also remarkable is the chimpanzeo's avidity for salt, which, if available, it will steal. On occasion, flesh is eaten, presumably the local hare or some new-born artiodactyl, and in this there was evidence of sharing of food by a dominant male with his partners.

The morning session concluded with some general discussion opened by Dr. W. C. Osman Hill (who here showed a film and demonstrated a tape recording of the ufiti-a lone chimpanzee recently reported from the Nkata Bay area of Nyasaland). This was followed by an appraisal of the papers by Dr. N. Tappen (Tulane).

The afternoon was devoted to papors by Dr. A. Kortlandt (Amsterdam), Dr. R. Andrew (Yale), J. A. H. van Hooff (Utrecht) and the Rev. J. Cole (Oxford). Kortlandt explained his views on protohominid behaviour based on his field studies of chimpanzees. He posed the question why the great apes have not developed more human behaviour since the basic qualitios are available, and compared their cultural progress with that of the australopithecines. His conclusion was that the protohominids were savannah dwellers, an environment evoking new ideas not demanded of forest dwelling pongids. $\mathrm{He}$ opined that the great apes could well have been protohominids that had been driven back to the forests.

Dr. Andrew contributed an account of an analysis of the vocal emissions of various primates illustrated by audiograms. He distinguished fundamentals from resonanees, giving examples of various utterances by Cercopithecus, Macaca, Theropithecus and Pan. He concluded that the voice of Cercocebus was closer to that of baboons than to Cercopithecus, etc.

Mr. Van Hooff outlined the historical development of studies in facial expression since Darwin's classical observations, and gave an account of his personal comparative ethological studies on the higher primates with reference to actiology, motivation and function. Facial expression could be analysed into movements of brows, eye-region. ears, the erection of coronal tufts and modifications of the mouth, angulus oris and lips. Some of the expressions served as social signals.

The Rev. J. Cole held a high opinion of the pigtailed macaque (Macaca nemestrina) as a subject for experimental research, especially in the field of neurophysiology. Outlining some of his experiments, he concluded that: (1) pig-tails show a dominant hand and foot individually varying from right to left; (2) colour has more significance than shape in choice experiments. A decreasing importance of the three scnse organs, vision, touch and hearing, in that order, seemed to stem from the effects of the natural environment.

Dr. J. S. Weiner showed a short film loaned by Dr. G. M. Vevers depicting the use of a tool by a captive capuchin monkey. The session terminated in a discussion opened by Dr. M. R. A. Chance.

The morning of the second day, under the chairmanship of Prof. J. Z. Young, was devoted to more specialized topics. In the morning, papers on functional anatomy wero delivered. Dr. J. Scott (Belfast) discussed factors determining skull form, paying special attention to the symphyseal region of the mandible, the development of brow-ridges and the recession of the snout, with subsequent changes in the direction of facial growth. In connexion with the latter, he emphasized the role of the septal cartilage which serves as a built-in epiphysis allowing for downward and forward growth and the production of a muzzle. Only in man is the growth vertical in direction.

Dr. C. E. Oxnard (Birmingham) followed with an account of his comparative osteomotrical and myological studies of the pectoral limb in reference to locomotor adaptations. This led to a brisk discussion on the definition of brachiation, semi-brachiators and kindred matters. The session concluded with a paper by Dr. G. E. Erikson (Harvard) on brachiation in New World monkeys contrasted with the phenomenon in anthropoid apes. It was pointed out that the higher platyrrhines (Lagothrix, Brachyteles, Ateles) are true brachiators. Evidence was specially deduced from studies of the little-known Brachyteles. The concluding discussion was led by Prof. A. J. E. Cave.

The afternoon session was devoted to various problems of genetic interest, under the chairmanship of Prof. L. S. Penrose, and opened with a discussion by John Hamerton (Guy's Hospital) on primate chromosomes. Some excellent photographs of gorilla chromosomes were exhibited. Dr. D. Franks (Cambridge) followed with romarks on blood-groups, and admitted that their study gave little information with regard to relationships. He reported that the $B$ group does not appear in Pan, while the $O$ group is lacking in Pongo and Hylobates lar. In $H$. moloch and Symphalangus only the B group is present. The A substance in Pan is not identical with human $\mathrm{A}^{1}$ or $A^{2}$. The $M$ antigen occurs in the rhesus monkey. As regards the $\mathrm{Rh}$ factor, Gorilla aligns with man, the other anthropoids do not.

Dr. L. Backman (Uppsala) described now techniques for separation of protein mixtures and discussed results as derived from their application to sorum proteins in primates. In electrophoresis experiments he found the speed of transfer of haptoglobin bands was similar in man and baboon, but faster in Cercopithecus and some species of Macaca; in Pan it is slower than in man.

Dr. N. Tappen (Tulane) discoursed on the relations between genetics and systematics in the study of primato evolution, drawing his data from material collected in East Africa. He discussed the chromosome numbers in Cercopithecus, Erythrocebus and Cercocebus and indicated three or four patterns within the first mentioned. He also drew evidence from paper electrophoresis, which indicated an apartness for Cercocebus which had a phenomenally slow-moving hæmoglobin.

The last day, under the chairmanship of Prof. W. Montagna, was devoted to films showing various aspects of primate behaviour. Dr. D. Morris exhibited and made comments on a film depicting chimpanze日 behaviour. Dr. W. C. Osman Hill commented on a film taken by Mr. David Attenborough (British Broadcasting Corporation) on his recent trip to Madagascar, and depieting Microcebus, Lemur fulvus, $L$. variegatus, Propithecus verreauxi and Indri, the last-mentioned accompanied by a sound track of the peculiar vocalizations. Prof. Hall commented on two films depicting baboon behaviour, one taken on his own expedition, the other originating from Dr. S. L. Washburn (California). The session concluded with Dr. Kortlandt's film of wild chimpanzees.

W. C. Osman Hinl 